\title{
Halomonas fontilapidosi sp. nov., a moderately halophilic, denitrifying bacterium
}

\author{
Carmen M. González-Domenech, Fernando Martínez-Checa, \\ Emilia Quesada and Victoria Béjar
}

Correspondence

Victoria Béjar

vbejar@ugr.es

\begin{abstract}
Microbial Exopolysaccharides Research Group, Department of Microbiology, Faculty of Pharmacy, Cartuja Campus, University of Granada, 18071 Granada, Spain
\end{abstract}

\begin{abstract}
We have made a polyphasic taxonomic study of strain $5 C \mathrm{R}^{\top}$, isolated from Fuente de Piedra, Málaga, southern Spain. The strain is a moderately halophilic, Gram-negative rod, oxidase-positive and motile by a single polar flagellum. It does not produce acids from sugars and shows respiratory metabolism, using oxygen, nitrate and nitrite as terminal electron acceptors. It requires $\mathrm{NaCl}$ and grows best with $5-7.5 \% \mathrm{w} / \mathrm{v}$ at temperatures of between 32 and $45{ }^{\circ} \mathrm{C}$ within a pH range of $6-8$. Its $16 \mathrm{~S}$ rRNA gene sequence indicates that strain $5 \mathrm{CR}^{\top}$ belongs to the genus Halomonas in the class Gammaproteobacteria. Its closest relatives are Halomonas alimentaria, $H$. nitroreducens, $H$. shengliensis and $H$. ventosae, with the type strains of which our strain showed 16S rRNA gene sequence similarity values of 96.7-97.8\%. DNA-DNA hybridization studies between strain $5 \mathrm{CR}^{\top}$ and $H$. ventosae CECT $5797^{\top}$, the phylogenetically nearest type strain, showed $40 \%$ relatedness. Its $\mathrm{G}+\mathrm{C}$ content is $65.7 \mathrm{~mol} \%$. Its major fatty acids are $\mathrm{C}_{18: 1} \omega 7 \mathrm{c}$ (31.36\%), $\mathrm{C}_{16: 0}(25.55 \%), \mathrm{C}_{16: 1} \omega 7 \mathrm{c} /$ iso- $\mathrm{C}_{15: 0} 2-\mathrm{OH}(23.23 \%), \mathrm{C}_{19: 0}$ cyclo $\omega 8 c(8.14 \%)$, $\mathrm{C}_{12: 0} 3-\mathrm{OH}(5.76 \%)$ and $\mathrm{C}_{10: 0}(2.22 \%)$ and the predominant respiratory lipoquinone is ubiquinone with nine isoprene units (Q-9). The proposed name for the novel species is Halomonas fontilapidosi sp. nov., strain $5 \mathrm{CR}^{\top}\left(=\mathrm{CECT} 7341^{\top}=\mathrm{LMG} 24455^{\mathrm{T}}\right)$ being the type strain.
\end{abstract}

The family Halomonadaceae of the class Gammaproteobacteria comprises seven genera, Carnimonas, Chromohalobacter, Cobetia, Halomonas, Halotalea, Modicisalibacter and Zymobacter (Euzéby, 2008). Chromohalobacter, Cobetia, Halomonas and Modicisalibacter are composed of halophilic bacteria whereas Carnimonas, Halotalea and Zymobacter contain non-halophilic bacteria (Ben Ali Gam et al., 2007; Garrity et al., 2005; Ntougias et al., 2007). The genus Halomonas currently contains more than 50 species (Euzéby, 2008). Its members are Gram-negative, rodshaped, non-sporulated, aerobic chemo-organotrophs, with predominantly respiratory metabolism, using oxygen, nitrate or nitrite as electron acceptors. Few Halomonas species produce acids from sugars (see Mata et al., 2002; Dobson \& Franzmann, 1996; Franzmann et al., 1988; Vreeland, 2005; Arahal et al., 2007). They are widely distributed throughout hypersaline environments. Some of them are recognized for their potential use in biotechnology (Margesin \& Schinner, 2001; Ventosa \& Nieto,

The GenBank/EMBL/DDBJ accession number for the $16 \mathrm{~S}$ rRNA gene sequence of strain $5 C R^{\top}$ is EU541349.

A dendrogram based on phenotypic characteristics, a transmission electron micrograph of a cell of strain $5 \mathrm{CR}^{\top}$ and a $16 \mathrm{~S}$ rRNA gene sequence-based maximum-parsimony tree are available as supplementary material with the online version of this paper.
1995), producing exopolysaccharides (Arias et al., 2003; Mata et al., 2006; Martínez-Checa et al., 2002), denitrifying (Peyton et al., 2001; Yoshie et al., 2006) or degrading aromatic compounds (García et al., 2004).

We have already described some novel halophilic taxa isolated from Fuente de Piedra (Málaga, Spain): Idiomarina fontislapidosi (Martínez-Cánovas et al., 2004c), Halomonas anticariensis (Martínez-Cánovas et al., 2004b) and strain 15CR of Halomonas cerina (González-Domenech et al., 2008a). Furthering our research into bacteria in this area, we subjected strain $5 \mathrm{CR}^{\mathrm{T}}$ to a polyphasic taxonomic investigation and as a result propose it as the type strain of a novel species.

Strain $5 \mathrm{CR}^{\mathrm{T}}$ was isolated from a soil sample collected from Fuente de Piedra, an endorreic, saline wetland in the province of Málaga in southern Spain. The strain was isolated, maintained and routinely grown in MY medium (Moraine \& Rogovin, 1966) supplemented with $7.5 \% \mathrm{w} / \mathrm{v}$ sea-salt solution (Rodríguez-Valera et al., 1981) at $32{ }^{\circ} \mathrm{C}$. The procedures followed for phenotypic characterization are described in Mata et al. (2002). Growth at different salt concentrations was determined in MY medium with the following sea-salt concentrations: $0,0.5,1,3,5,7.5,10,15$, 20, 25 and $30 \% \mathrm{w} / \mathrm{v}$. pH tolerance between 5 and 10 was determined in MY medium containing $7.5 \% \mathrm{w} / \mathrm{v}$ sea salts. 
The temperature range was tested in a similar medium by incubating the bacterium at temperatures of $4,15,20,25$, $32,37,45$ and $50{ }^{\circ} \mathrm{C}$ at $\mathrm{pH}$ 7. Denitrifying ability was tested by conducting a respiratory assay according to the method of Callies \& Mannheim (1978) with modifications by Stanier et al. (1966). This assay consists of growing the bacterium in a Weinberg tube under anaerobic conditions, with nitrate or nitrite as sole electron acceptor. We used phenol red as $\mathrm{pH}$ indicator in the medium to avoid any possibility of a false-positive result caused by a fermentative metabolism. We compared the novel strain with the type strains of 31 species of Halomonas by means of a numerical analysis based on data deriving from 104 phenotypic characteristics. Computer analysis was done with the NTSYSpc program, version 2.0 (Applied Biostatistics, Inc.). A dendrogram showing the clustering of strain $5 \mathrm{CR}^{\mathrm{T}}$ and type strains of other species of Halomonas is available as Supplementary Fig. S1 (available in IJSEM Online). The closest species phenotypically were Halomonas cerina and Halomonas desiderata $(73.25 \%$ similarity with both species).

The characteristics of strain $5 \mathrm{CR}^{\mathrm{T}}$ are given in the species description. Phenotypic features that distinguish the novel species from other phenotypically and phylogenetically related species of Halomonas are included in Table 1. Strain $5 \mathrm{CR}^{\mathrm{T}}$ and Halomonas species included in Table 1 shared the following features: Gram-negative rods, positive for oxidase and catalase but negative for haemolysis and the hydrolysis of starch, aesculin and casein. Their metabolism is respiratory. They are all able to respire on nitrate and nitrite anaerobically as well as aerobically. They produce acids from sugars.

The fatty acids and quinones of strain $5 \mathrm{CR}^{\mathrm{T}}$ were analysed at the Deutsche Sammlung von Mikroorganismen und Zellkulturen (DSMZ) by high-resolution GLC and HPLC respectively. To this end, strain $5 \mathrm{CR}^{\mathrm{T}}$ was grown in $\mathrm{MY}$ medium (Moraine \& Rogovin, 1966) with $7.5 \%$ w/v seasalt solution (Rodríguez-Valera et al., 1981) at $32{ }^{\circ} \mathrm{C}$. The strain contained a combination of fatty acids found in species of Halomonas (Dobson \& Franzmann, 1996), predominantly $\mathrm{C}_{18: 1} \omega 7 c \quad(31.36 \%), \mathrm{C}_{16: 0} \quad(25.55 \%)$, $\mathrm{C}_{16: 1} \omega 7 c /$ iso- $\mathrm{C}_{15: 0} \quad 2-\mathrm{OH} \quad(23.23 \%), \mathrm{C}_{19: 0}$ cyclo $\omega 8 c$ $(8.14 \%), \mathrm{C}_{12: 0} 3-\mathrm{OH}(5.76 \%)$ and $\mathrm{C}_{10: 0}(2.22 \%)$. An analysis of the quinones showed that the strain contained ubiquinone with nine isoprene units (Q-9) as the predominant respiratory lipoquinone (92\%); it also contained a small quantity $(8 \%)$ of ubiquinone 8 .

Transmission electron micrographs obtained using the methods of Bouchotroch et al. (2001) revealed the strain's size and cell morphology and its single flagellum (Supplementary Fig. S2).

The DNA of strain $5 \mathrm{CR}^{\mathrm{T}}$ was extracted by the method of Marmur (1961). The G+C content of the DNA was estimated from the midpoint value $\left(T_{\mathrm{m}}\right)$ of the thermal denaturation profile (Marmur \& Doty, 1962) using the equation of Owen \& Hill (1979). The G + C content of reference DNA from Escherichia coli NCTC $9001^{\mathrm{T}}$ was taken to be $50.9 \mathrm{~mol} \%$ (Owen \& Pitcher, 1985). The G+C content of the novel strain was $65.7 \mathrm{~mol} \%$. This result is similar to others from denitrifying bacteria but somewhat lower than the $\mathrm{G}+\mathrm{C}$ content of Halomonas ventosae (74.3 $\mathrm{mol} \%$ ).

Phylogenetic analyses based on the 16S rRNA gene were made as described in Bouchotroch et al. (2001). The sequences were compared to reference 16S rRNA gene sequences available in the GenBank and EMBL databases obtained from the National Center of Biotechnology Information database using the BLAST search. Phylogenetic analyses were carried out using the software MEGA version 4 (Tamura et al., 2007) after multiple alignments of the data by CLUSTAL_X (Thompson et al., 1997). Distances and clustering with the neighbour-joining and maximum-parsimony methods were determined by using bootstrap values based on 1000 replications.

We determined almost the entire 16S rRNA gene sequence of strain $5 \mathrm{CR}^{\mathrm{T}}(1411 \mathrm{bp})$. The fragment analysed contained the 15 signature nucleotides defined for the family Halomonadaceae and the four defined for the genus Halomonas (Dobson \& Franzmann, 1996). The phylogenetic tree constructed using the neighbour-joining algorithm appears in Fig. 1; the phylogenetic tree constructed using the maximum-parsimony algorithm is available as Supplementary Fig. S3. The most phylogenetically related species are all denitrifying species: Halomonas alimentaria, $H$. nitroreducens, $H$. shengliensis and $H$. ventosae, with the type strains of which our strain shows 16S rRNA gene sequence similarity values of $97.0,97.5,96.7$ and $97.8 \%$, respectively. The trees obtained by the two methods show that $5 \mathrm{CR}^{\mathrm{T}}$ formed a separate lineage in the genus Halomonas and warrants placement within a novel species. Evolutionary distances, including a correction factor for reverse mutations (Jukes \& Cantor, 1969), were calculated for sequence pairs by using a 'mask' (Lane, 1991) for nonhomologous or uncertain nucleotide positions.

DNA-DNA hybridization was undertaken by two methods, the method of Lind \& Ursing (1986), with the modifications of Ziemke et al. (1998) and Bouchotroch et al. (2001), and the spectroscopic DNA-DNA hybridization technique performed by the DSMZ. The latter method consists of isolating and purifying DNA by chromatography on hydroxyapatite as described by Cashion et al. (1977), followed by DNA-DNA hybridization as described by De Ley et al. (1970) and modified by Huß et al. (1983). The results of DNA-DNA hybridization revealed approximately $40 \%$ relatedness between strain $5 \mathrm{CR}^{\mathrm{T}}$ and $H$. ventosae CECT $5797^{\mathrm{T}}$, the closest phylogenetic relative, with both methods ( 40.3 and $40.8 \%$ respectively).

The differences in $\mathrm{G}+\mathrm{C}$ content, the similarity of its $16 \mathrm{~S}$ rRNA gene sequence, the DNA-DNA hybridization values and the phenotypic and chemotaxonomic data show that the novel strain was not related closely enough to belong to any Halomonas species described to date and thus, on the 
Table 1. Distinguishing characteristics of Halomonas species phenotypically and phylogenetically related to strain $5 \mathrm{CR}^{\top}$

Reference type strains: 1, H. alimentaria DSM $15356^{\mathrm{T}}$ (data from this study and from Yoon et al., 2002); 2, H. cerina CECT $7282^{\mathrm{T}}$ (GonzálezDomenech et al., 2008a); 3, H. desiderata DSM 9502 ${ }^{\mathrm{T}}$ (Berendes et al., 1996; Mata et al., 2002); 4, H. nitroreducens CECT $7281^{\mathrm{T}}$ (GonzálezDomenech et al., 2008b); 5, H. shengliensis LMG 23897 (Wang et al., 2007); 6, H. ventosae CECT 5797 ${ }^{\mathrm{T}}$ (Martínez-Cánovas et al., 2004a). + +, Strongly positive; + , positive; D, doubtful; - , negative; ND, no data available.

\begin{tabular}{|c|c|c|c|c|c|c|c|}
\hline Characteristic & $5 \mathrm{CR}^{\mathrm{T}}$ & 1 & 2 & 3 & 4 & 5 & 6 \\
\hline Morphology* & SR & $\mathrm{C} / \mathrm{SR}$ & SR & $\mathrm{R}$ & $\mathrm{R}$ & SR & $\mathrm{R}$ \\
\hline Cell width $(\mu \mathrm{m})$ & $0.9-1.0$ & $0.8-1.2$ & $0.7-0.9$ & $0.4-0.6$ & $0.4-0.5$ & $0.6-0.8$ & $0.7-0.8$ \\
\hline Cell length $(\mu \mathrm{m})$ & $1.7-1.9$ & $1.3-1.9$ & $1.9-2.8$ & $1.0-2.6$ & $1.5-2.2$ & $1.0-1.6$ & $1.2-1.4$ \\
\hline Pigmentation $\dagger$ & CRB & CRY $\ddagger$ & wx & CR & CRW & CRB & $\mathrm{CR}$ \\
\hline Exopolysaccharide production & - & - & + & - & ++ & - & ++ \\
\hline Motility & + & - & - & + & - & + & + \\
\hline Flagellation & Polar & Absent & Absent & Peritrichous & Absent & Lateral & Lateral \\
\hline \multicolumn{8}{|c|}{ Sea-salt concentration for growth $(\% \mathrm{w} / \mathrm{v})$} \\
\hline Range & $3-25$ & $0-30$ & $3-25$ & $0-20$ & $0.5-30$ & $0.5-30$ & $1-15$ \\
\hline Optimum & $7.5-10$ & $1-13$ & $7.5-10$ & $1-5$ & $3-5$ & $5-15$ & 8 \\
\hline \multicolumn{8}{|l|}{$\mathrm{pH}$ for growth } \\
\hline Range & $5-9$ & $5-10$ & $5-10$ & $7-11$ & $5-10$ & $5-10$ & $6-10$ \\
\hline Optimum & $6-8$ & $6.5-7.5$ & $7-8$ & 9.5 & $7-9$ & 8.5 & $7-8$ \\
\hline \multicolumn{8}{|l|}{ Temperature for growth $\left({ }^{\circ} \mathrm{C}\right)$} \\
\hline Range & $15-45$ & $4-45$ & $4-45$ & $10-45$ & $4-45$ & $4-45$ & $15-50$ \\
\hline Optimum & $32-45$ & 30 & $20-32$ & $37-42$ & $20-32$ & 30 & 32 \\
\hline Strictly halophilic & Yes & No & Yes & No & Yes & Yes & Yes \\
\hline \multicolumn{8}{|l|}{ Hydrolysis of: } \\
\hline Gelatin & - & - & - & - & + & - & - \\
\hline Tween 20 & + & + & + & + & - & + & + \\
\hline Tween 80 & - & - & + & + & - & - & - \\
\hline DNA & + & + & + & + & + & - & - \\
\hline Tyrosine & + & - & + & + & + & - & + \\
\hline Tyrosine pigment & + & - & - & - & - & - & - \\
\hline $\mathrm{H}_{2} \mathrm{~S}$ generation & + & + & - & + & + & + & + \\
\hline Lecithinase & + & - & - & - & - & - & - \\
\hline Phosphatase & - & - & + & + & - & + & - \\
\hline Urease & - & + & + & + & + & + & - \\
\hline Gluconate oxidation & + & + & + & + & - & - & + \\
\hline \multicolumn{8}{|l|}{ Growth on: } \\
\hline MacConkey agar & - & + & + & + & + & + & - \\
\hline Cetrimide agar & - & - & - & + & + & + & - \\
\hline \multicolumn{8}{|l|}{ Growth on: $§$} \\
\hline Aesculin & - & - & - & - & - & - & + \\
\hline L-Arabinose & + & + & - & + & - & - & - \\
\hline Cellobiose & - & + & - & - & - & + & - \\
\hline D-Fructose & + & - & - & + & + & - & + \\
\hline D-Galactose & + & + & - & - & + & + & + \\
\hline D-Glucose & + & + & + & - & + & + & + \\
\hline Maltose & + & + & + & + & + & - & + \\
\hline D-Mannose & + & + & + & + & + & + & - \\
\hline D-Salicin & - & - & + & - & - & + & - \\
\hline Starch & + & + & - & + & + & + & - \\
\hline Trehalose & - & + & - & + & + & + & + \\
\hline Acetate & - & + & + & + & + & + & + \\
\hline Citrate & + & + & + & - & + & - & + \\
\hline Formate & - & - & - & + & - & - & - \\
\hline Fumarate & - & + & + & + & + & + & + \\
\hline Malonate & - & + & - & + & - & + & + \\
\hline Propionate & - & + & - & - & + & + & + \\
\hline Adonitol & + & - & - & - & - & + & + \\
\hline
\end{tabular}


Table 1. cont.

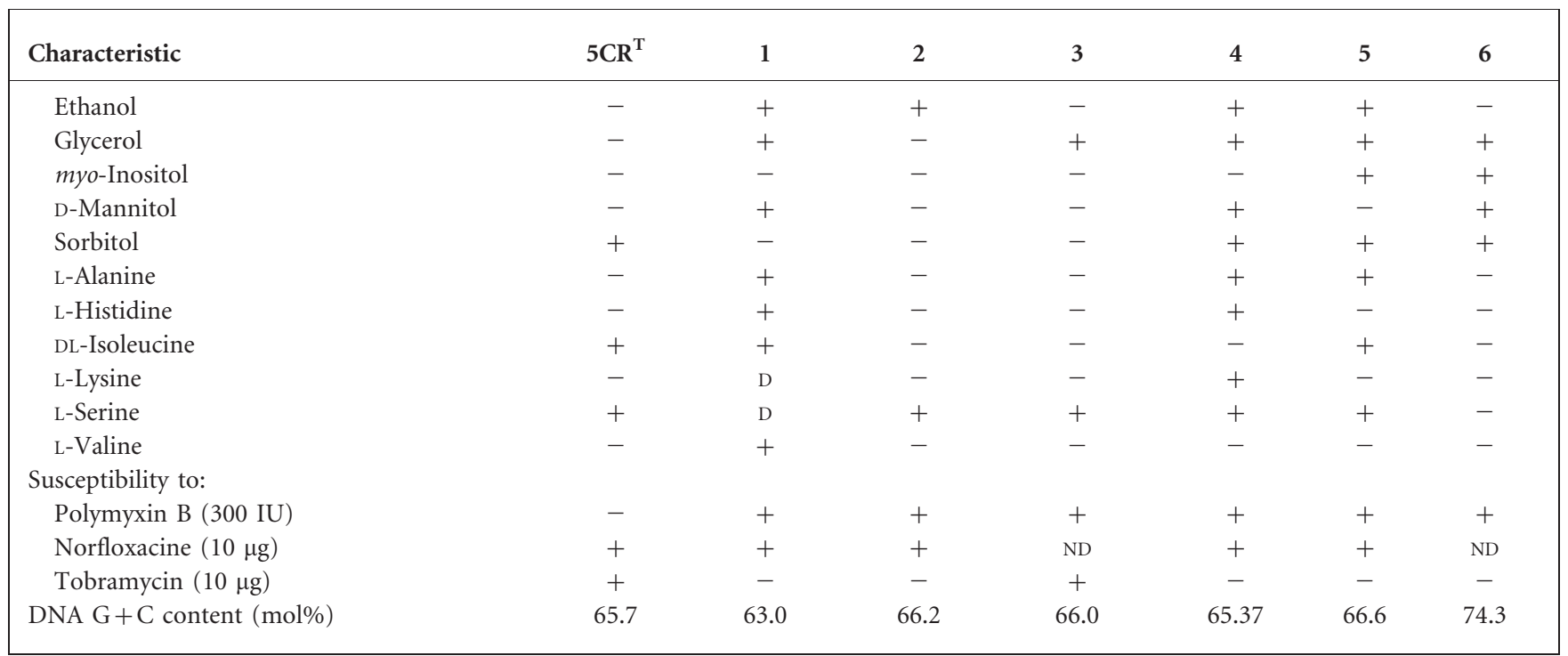

${ }^{*} \mathrm{C}$, Coccus; $\mathrm{R}$, rod; SR, short rod.

$\dagger \mathrm{CR}$, Cream; CRB, cream-brown; CRW, cream-white; CRY, cream-yellow; wX, wax-coloured.

‡On marine agar.

§When supplied as the sole source of carbon and energy and carbon, nitrogen and energy.

basis of the data discussed and the full description provided below, we propose a novel species, Halomonas fontilapidosi sp. nov., to include strain $5 \mathrm{CR}^{\mathrm{T}}$.

\section{Description of Halomonas fontilapidosi sp. nov.}

Halomonas fontilapidosi (fon.ti.la.pi.do'si. L. n. fons -tis spring; L. adj. lapidosus stony; N.L. gen. n. fontilapidosi of the stony spring, i.e. from Fuente de Piedra, the site from which the type strain was isolated).

Cells are Gram-negative rods, $0.96 \times 1.73 \mu \mathrm{m}$ (means of five measurements). The cells are motile by a single polar flagellum and contain poly- $\beta$-alkanoate granules. It does not produce exopolysaccharide or form endospores. Cell colonies are circular, convex and creamy-brown in colour. Its growth pattern is uniform in a liquid medium. It is moderately halophilic and incapable of growing without $\mathrm{NaCl}$; it grows at sea-salt concentrations of between 3 and $25 \% \mathrm{w} / \mathrm{v}$ (optimum $7.5-10 \% \mathrm{w} / \mathrm{v}$ ) and $\mathrm{NaCl}$ concentrations of between 3 and $20 \% \mathrm{w} / \mathrm{v}$ (optimum $5-7.5 \% \mathrm{w} / \mathrm{v}$ ). It grows within a temperature range of $15-45^{\circ} \mathrm{C}$ and at $\mathrm{pH}$ values of between 5 and 9, the optimum values being 32 $45{ }^{\circ} \mathrm{C}$ and $\mathrm{pH}$ 6-8. It resists heating to $80{ }^{\circ} \mathrm{C}$ for $10 \mathrm{~min}$. It is chemo-organotrophic and catalase- and oxidase-positive. Its metabolism is of the respiratory type with oxygen, nitrate and nitrite as terminal electron acceptors. It produces gas from nitrate and nitrite in anaerobiosis. Respiration with fumarate is negative. It produces $\mathrm{H}_{2} \mathrm{~S}$ from L-cysteine, DNase and phenylalanine deaminase but not phosphatase. Gluconate is oxidized. It does not produce acids from adonitol, D-fructose, D-galactose,
D-glucose, myo-inositol, lactose, maltose, D-mannitol, Dmannose, melezitose, L-rhamnose, sucrose, D-salicin, Dsorbitol, sorbose or trehalose. Indole, methyl red, O/F, ONPG and Voges-Proskauer tests are negative. Reduction of selenite, nitrate and nitrite is positive. It hydrolyses tyrosine and produces pigment from it. It hydrolyses Tween 20 and lecithin, but not aesculin, starch, Tween 80 , urea, gelatin, casein or blood. It does not grow on either MacConkey agar or cetrimide agar. The following compounds are acceptable as sole carbon and energy sources: adonitol, L-arabinose, citrate, D-fructose, lactose, D-galactose, gluconate, D-glucose, lactate, maltose, D-mannose, sorbitol, starch and succinate. The following compounds are not acceptable as sole carbon and energy sources: acetate, aesculin, cellobiose, ethanol, formate, fumarate, DLglycerol, D-mannitol, myo-inositol, malonate, propionate, D-salicin and trehalose. DL-Isoleucine and L-serine are used as sole sources of carbon, nitrogen and energy. L-Alanine, L-cysteine, L-lysine, L-histidine, L-methionine and L-valine are not used as sole sources of carbon, nitrogen and energy. It is susceptible to amoxicillin $(25 \mu \mathrm{g})$, cefalothin $(30 \mu \mathrm{g})$, cefoxitin $(30 \mu \mathrm{g})$, ceftazidime $(30 \mu \mathrm{g})$, doxycycline $(30 \mu \mathrm{g})$, gentamicin $(10 \mu \mathrm{g})$, nalidixic acid $(30 \mu \mathrm{g})$, nitrofurantoin (300 IU), norfloxacine $(10 \mu \mathrm{g})$, rifampicin $(30 \mu \mathrm{g})$, sulfamide $(250 \mu \mathrm{g})$, trimethoprim/sulfamethoxazole (1.25/ $23.75 \mu \mathrm{g})$, tobramycin $(10 \mu \mathrm{g})$ and vancomycin $(30 \mu \mathrm{g})$. It is resistant to polymyxin $\mathrm{B}$ (300 IU). Principal fatty acids are $\mathrm{C}_{18: 1} \omega 7 c, \mathrm{C}_{16: 0}$ and $\mathrm{C}_{16: 1} \omega 7 c /$ iso- $\mathrm{C}_{15: 0}$ 2-OH. The predominant respiratory lipoquinone is ubiquinone with nine isoprene units (Q-9). The DNA G+C content of the type strain is $65.7 \mathrm{~mol} \%$ ( $T_{\mathrm{m}}$ method). 


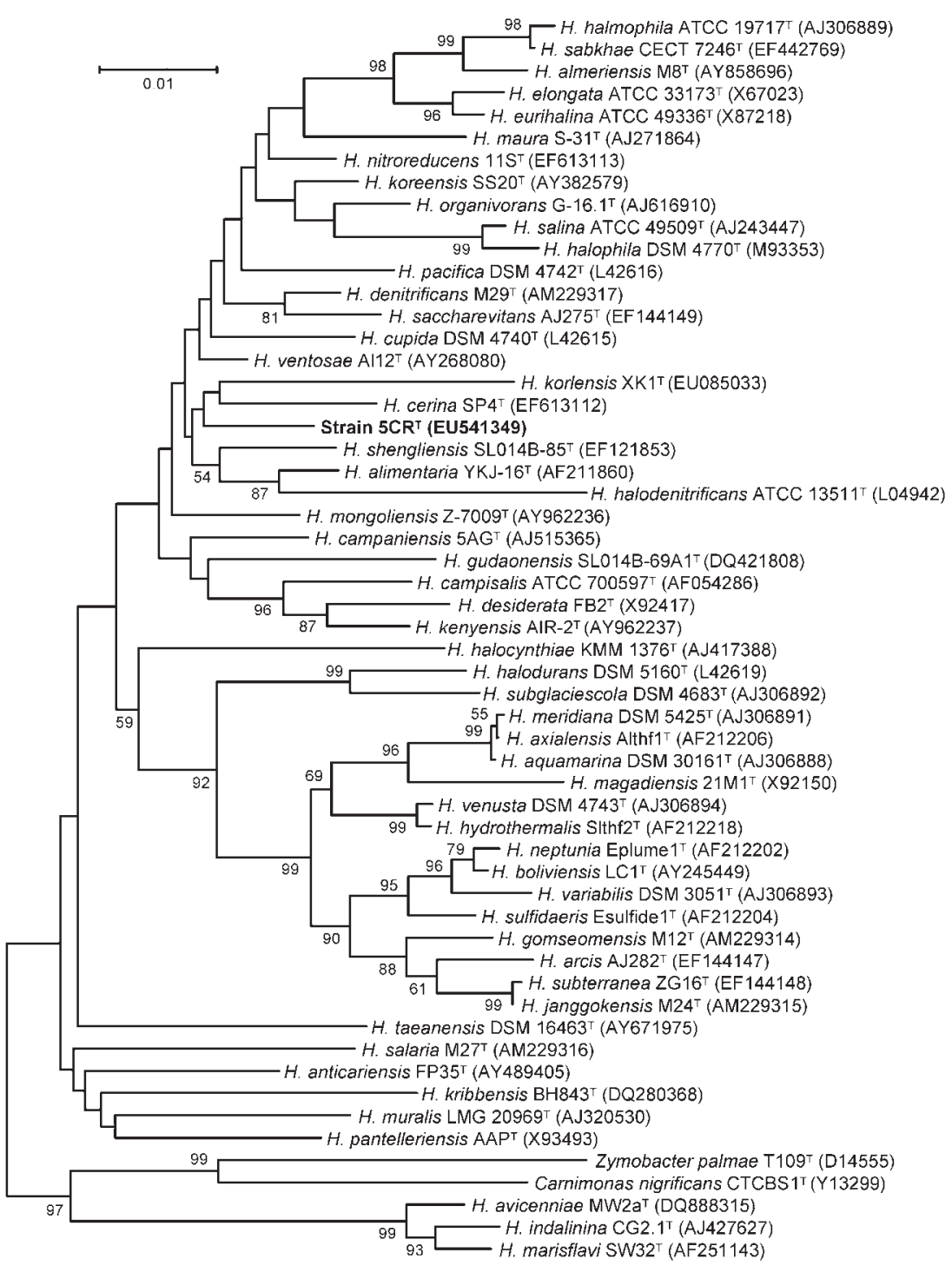

Fig. 1. Phylogenetic tree, based on $16 \mathrm{~S}$ rRNA gene sequences, showing the position of the novel isolate with respect to other members of the family Halomonadaceae. The tree was obtained using the neighbour-joining algorithm. GenBank/EMBL/DDBJ accession numbers are given in parentheses. Bar, 1\% sequence divergence. Bootstrap values (expressed as percentages of 1000 replications) greater than $50 \%$ are shown at branch points.
The type strain is strain $5 \mathrm{CR}^{\mathrm{T}}$ (=CECT $7341^{\mathrm{T}}=\mathrm{LMG}$ $24455^{\mathrm{T}}$ ), isolated from saline soil at Fuente de Piedra (Málaga, Spain).

\section{Acknowledgements}

This research was supported by grants from the Dirección General de Investigación Científica y Técnica (BOS2003-0498; CGL2005-05947) and from the Plan Andaluz de Investigación, Spain. Thanks go to Cristina Ruiz García, who isolated the strain, and to Concepción Hernández and David Porcel from the Centro de Instrumentación Científica (University of Granada) for their expertise in microscope studies. We acknowledge Dr Jean Euzéby for his advice on naming our species. We also thank our colleague Dr J. Trout for revising our English text.

\section{References}

Arahal, D. R., Vreeland, R. H., Litchfield, C. D., Mormile, M. R., Tindall, B. J., Oren, A., Béjar, V., Quesada, E. \& Ventosa, A. (2007).
Recommended minimal standards for describing new taxa of the family Halomonadaceae. Int J Syst Evol Microbiol 57, 2436-2446.

Arias, S., Del Moral, A., Ferrer, M. R., Quesada, E. \& Béjar, V. (2003). Mauran, an exopolysaccharide produced by the halophilic bacterium Halomonas maura, with a novel composition and interesting properties for biotechnology. Extremophiles 7, 319326.

Ben Ali Gam, Z., Abdelkafi, S., Casalot, L., Tholozan, J. L., Oueslati, R. \& Labat, M. (2007). Modicisalibacter tunisiensis gen. nov., sp. nov., an aerobic, moderately halophilic bacterium isolated from an oilfieldwater injection sample, and emended description of the family Halomonadaceae Franzmann et al. 1989 emend. Dobson and Franzmann 1996 emend. Ntougias et al. 2007. Int J Syst Evol Microbiol 57, 2307-2313.

Berendes, F., Gottschalk, G., Heine-Dobbernack, E., Moore, E. R. B. \& Tindall, B. J. (1996). Halomonas desiderata sp. nov., a new alkaliphilic, halotolerant and denitrifying bacterium isolated from a municipal sewage works. Syst Appl Microbiol 19, 158-167.

Bouchotroch, S., Quesada, E., Del Moral, A., Llamas, I. \& Béjar, V. (2001). Halomonas maura sp. nov., a novel moderately halophilic, 
exopolysaccharide-producing bacterium. Int J Syst Evol Microbiol 51, 1625-1632.

Callies, E. \& Mannheim, E. (1978). Classification of the Flavobacterium-Cytophaga complex on the basis of respiratory quinones and fumarate respiration. Int J Syst Bacteriol 28, 14-19.

Cashion, P., Holder-Franklin, M. A., McCully, J. \& Franklin, M. (1977). A rapid method for the base ratio determination of bacterial DNA. Anal Biochem 81, 461-466.

De Ley, J., Cattoir, H. \& Reynaerts, A. (1970). The quantitative measurement of DNA hybridization from renaturation rates. Eur $J$ Biochem 12, 133-142.

Dobson, S. J. \& Franzmann, P. D. (1996). Unification of the genera Deleya (Baumann et al. 1993), Halomonas (Vreeland et al. 1980), and Halovibrio (Fendrich 1988) and the species Paracoccus halodenitrificans (Robinson and Gibbons 1952) into a single genus, Halomonas, and placement of the genus Zymobacter in the family Halomonadaceae. Int J Syst Bacteriol 46, 550-558.

Euzéby, J. P. (2008). Halomonas Vreeland et al. 1980. In List of Prokaryotic Names with Standing in Nomenclature. http://www.bacterio.cict.fr/h/halomonas.html

Franzmann, P. D., Wehmeyer, U. \& Stackebrandt, E. (1988). Halomonadaceae fam. nov., a new family of the class Proteobacteria to accommodate the genera Halomonas and Deleya. Syst Appl Microbiol 11, 16-19.

García, M. T., Mellado, E., Ostos, J. C. \& Ventosa, A. (2004). Halomonas organivorans sp. nov., a moderate halophile able to degrade aromatic compounds. Int J Syst Evol Microbiol 54, 1723-1728.

Garrity, G. M., Bell, J. A. \& Lilburn, T. (2005). Family IV. Halomonadaceae Franzmann, Wehmeyer and Stackebrandt 1989, $205^{\mathrm{VP}}$ emend. Dobson and Franzmann 1996, 558. In Bergey's Manual of Systematic Bacteriology, 2nd edn, vol. 2, part B, p. 300. Edited by D. J. Brenner, N. R. Krieg, J. T. Staley \& G. M. Garrity. New York: Springer.

González-Domenech, C. M., Martínez-Checa, F., Quesada, E. \& Béjar, V. (2008a). Halomonas cerina sp. nov., a moderately halophilic, denitrifying, exopolysaccharide-producing bacterium. Int J Syst Evol Microbiol 58, 803-809.

González-Domenech, C. M., Béjar, V., Martínez-Checa, F. \& Quesada, E. (2008b). Halomonas nitroreducens sp. nov., a novel nitrate- and nitrite-reducing species. Int J Syst Evol Microbiol 58, 872876.

Huß, V. A. R., Festl, H. \& Schleifer, K. H. (1983). Studies on the spectrophotometric determination of DNA hybridization from renaturation rates. Syst Appl Microbiol 4, 184-192.

Jukes, T. H. \& Cantor, C. R. (1969). Evolution of protein molecules. In Mammalian Protein Metabolism, vol. 3, pp. 21-132. Edited by H. N. Munro. New York: Academic Press.

Lane, D. J. (1991). 16S/23S rRNA sequencing. In Nucleic Acid Techniques in Bacterial Systematics, pp. 115-175. Edited by E. Stackebrandt \& M. Goodfellow. Chichester: Wiley.

Lind, E. \& Ursing, J. (1986). Clinical strains of Enterobacter agglomerans (synonyms, Erwinia herbicola, Erwinia milletiae) identified by DNA-DNA hybridization. Acta Pathol Microbiol Immunol Scand Sect B 94, 205-213.

Margesin, R. \& Schinner, F. (2001). Potential of halotolerant and halophilic microorganisms for biotechnology. Extremophiles 5, 73-83.

Marmur, J. (1961). A procedure for the isolation of deoxyribonucleic acid from microorganisms. J Mol Biol 3, 208-218.

Marmur, J. \& Doty, P. (1962). Determination of the base composition of deoxyribonucleic acid from its thermal denaturation temperature. J Mol Biol 5, 109-118.
Martínez-Cánovas, M. J., Quesada, E., Llamas, I. \& Béjar, V. (2004a). Halomonas ventosae sp. nov., a moderately halophilic, denitrifying, exopolysaccharide-producing bacterium. Int J Syst Evol Microbiol 54, 733-737.

Martínez-Cánovas, M. J., Béjar, V., Martínez-Checa, F. \& Quesada, E. (2004b). Halomonas anticariensis sp. nov., from Fuente de Piedra, a saline-wetland wildfowl reserve in Málaga, southern Spain. Int J Syst Evol Microbiol 54, 1329-1332.

Martínez-Cánovas, M. J., Béjar, V., Martínez-Checa, F., Páez, R. \& Quesada, E. (2004c). Idiomarina fontislapidosi sp. nov. and Idiomarina ramblicola sp. nov., isolated from inland hypersaline habitats in Spain. Int J Syst Evol Microbiol 54, 1793-1797.

Martínez-Checa, F., Toledo, F. L., Vilchez, R., Quesada, E. \& Calvo, C. (2002). Yield production, chemical composition and functional properties of emulsifier $\mathrm{H} 28$ synthesized by Halomonas eurihalina strain H-28 in media containing various hydrocarbons. Appl Microbiol Biotechnol 58, 358-363.

Mata, J. A., Martínez-Cánovas, M. J., Quesada, E. \& Béjar, V. (2002). A detailed phenotypic characterization of the type strains of Halomonas species. Syst Appl Microbiol 25, 360-375.

Mata, J. A., Béjar, V., Llamas, I., Arias, S., Bressollier, P., Tallon, R., Urdaci, M. C. \& Quesada, E. (2006). Exopolysaccharides produced by the recently described halophilic bacteria Halomonas ventosae and Halomonas anticariensis. Res Microbiol 157, 827-835.

Moraine, R. A. \& Rogovin, P. (1966). Kinetics of polysaccharide B1459 fermentation. Biotechnol Bioeng 8, 511-524.

Ntougias, S., Zervakis, G. I. \& Fasseas, C. (2007). Halotalea alkalilenta gen. nov., sp. nov., a novel osmotolerant and alkalitolerant bacterium from alkaline olive mill wastes, and emended description of the family Halomonadaceae Franzmann et al. 1989, emend. Dobson and Franzmann 1996. Int J Syst Evol Microbiol 57, 1975-1983.

Owen, R. J. \& Hill, L. R. (1979). The estimation of base compositions, base pairing and genome sizes of bacterial deoxyribonucleic acids. In Identification Methods for Microbiologists (Society for Applied Bacteriology Technical Series no. 14), 2nd edn, pp. 277-296. Edited by F. A. Skinner \& D. W. Lovelock. London: Academic Press.

Owen, R. J. \& Pitcher, D. (1985). Current methods for estimating DNA base composition and levels of DNA-DNA hybridization. In Chemical Methods in Bacterial Systematics, pp. 67-93. Edited by M. Goodfellow \& E. Minnikin. London: Academic Press.

Peyton, B. M., Mormile, M. R. \& Peterson, N. J. (2001). Nitrate reduction with Halomonas campisalis. Kinetics of denitrification at pH 9 and $12.5 \%$ NaCl. Water Res 35, 4237-4242.

Rodríguez-Valera, F., Ruiz-Berraquero, F. \& Ramos-Cormenzana, A. (1981). Characteristics of the heterotrophic bacterial populations in hypersaline environments of different salt concentrations. Microb Ecol 7, 235-243.

Stanier, R. Y., Palleroni, N. J. \& Doudoroff, M. (1966). The aerobic pseudomonads: a taxonomic study. J Gen Microbiol 43, 159-271.

Tamura, K., Dudley, J., Nei, M. \& Kumar, S. (2007). MEGA4: molecular evolutionary genetics analysis (MEGA) software version 4.0. Mol Biol Evol 24, 1596-1599.

Thompson, J. D., Gibson, T. J., Plewniak, F., Jeanmougin, F. \& Higgins, D. G. (1997). The CLUSTAL_X windows interface: flexible strategies for multiple sequence alignment aided by quality analysis tools. Nucleic Acids Res 25, 4876-4882.

Ventosa, A. \& Nieto, J. J. (1995). Biotechnological applications and potentialities of halophilic microorganisms. World J Microbiol Biotechnol 11, 85-94.

Vreeland, R. H. (2005). Genus Halomonas Vreeland, Litchfield, Martin, and Elliot 1980, 494 ${ }^{\mathrm{VP}}$ emend. Dobson and Franzmann 1996, 557. In Bergey's Manual of Systematic Bacteriology, 2nd edn, vol. 2, 
part B, pp. 300-313. Edited by D. J. Brenner, N. R. Krieg, J. T. Staley \& G. M. Garrity. New York: Springer.

Wang, Y. N., Cai, H., Chi, C. Q., Lu, A. H., Lin, X. G., Jiang, Z. F. \& Wu, X. L. (2007). Halomonas shengliensis sp. nov., a moderately halophilic, denitrifying, crude-oil-utilizing bacterium. Int J Syst Evol Microbiol 57, 1222-1226.

Yoon, J. H., Lee, K. C., Kho, Y. H., Kang, K. H., Kim, C. J. \& Park, Y. H.

(2002). Halomonas alimentaria sp. nov., isolated from jeotgal, a traditional Korean fermented seafood. Int J Syst Evol Microbiol 52, 123-130.

Yoshie, S., Ogawa, T., Makino, H., Hirosawa, H., Tsuneda, S. \& Hirata, A. (2006). Characteristics of bacteria showing high denitrification activity in saline wastewater. Lett Appl Microbiol 42, 277-283.

Ziemke, F., Manfred, G. H., Lalucat, J. \& Rosselló-Mora, R. (1998). Reclassification of Shewanella putrefaciens Owen's genomic group II as Shewanella baltica sp. nov. Int J Syst Bacteriol 48, 179-186. 